Diterbitkan oleh Pusat Studi Gender dan Anak LP2M IAIN Syekh Nurjati Cirebon, Indonesia

\title{
UPAYA MENINGKATKAN KECERDASAN INTERPERSONAL DAN INTRAPERSONAL MELALUI PEMBELAJARAN TEMATIK DI TK ZULHIJJAH MEDAN
}

\section{Armanila*}

UIN Sunan Kalijaga armanila88@gmail.com

\section{-Received: 19 Nov 2019 •Accepted: 4 Des 2019 •Published online: 11 Des 2019}

Abstract: The objective of this research is to know the increasing interpersonal and intrapersonal intelligence of early childhood (5-6 years old) through thematic learning. This study was conducted of the first semester of Zulhijjah kindergarten in 2014 academic year. The methodological of this research was used classroom action research method by applied"Kemmis and Taggart"model and used two cycle, which consist of four steps as follows: 1) planning, 2) implementation, 3) observation, 4) reflection. The point of new of this study is 10 children of B class at Zulhijjah kindergarten Medan. Based on the concept of classroom action research that has mixed paradigma method, namely quantitative and qualitative research methods. The quantitative data was analyzed by using t-test, paired samples (t-paired samples) to know of increasing of interpersonal and intrapersonal intelligence before and after done the action, then to show the difference each cycles. And qualitative data was analyzed based in the observation result that has done. The result of this research shows that there is a significant different in increasing interpersonal and intrapersonal intelligence through thematic learning in pre and post assesment. After counted the data that had found from the field by using t-test formula, the result of counting is as follows: 1) interpersonal intelligence of $t$-test $=-19,844$ lower than $t$-table $=2,262.2$ ) intrapersonal intelligence of $t$-tes $=-18,253$ lower than $t$-table $=2,262$, by that, it can be told that, there is an increasing between the first and in the final assesment in the level of confidence /trust $95 \%$ to interpersonal and intrapersonal intelligence. It can be seen in preaction too, which average value of interpersonal intelligence as big as 40,62\%, then in cycle I increase to $64,79 \%$, and in the final cycle II has been reached $80,41 \%$. From the finding of the research can be concluded that to increase interpersonal and intrapersonal intelligence of early chilhood (5-6 years old) need to pay attention the thematic learning that is used.

Keywords: interpersonal, intrapersonal intelligence, thematic learning.

Abstrak: Penelitian ini bertujuan untuk mengetahui peningkatan kecerdasan interpersonal dan intrapersonal anak usia dini (5-6 tahun) melalui pembelajaran tematik. Penelitian dilakukan pada Taman Kanak-kanak Zulhijjah Medan selama semester pertama tahun pembelajaran 2014. Secara metodologi penelitian ini merupakan penelitian tindakan kelas (classroom action research) dengan menerapkan model"Kemmis dan Taggart"dalam dua siklus, dengan tahapan sebagai berikut: 1) perencanaan, 2) pelaksanaan, 3) pengamatan, 4) refleksi. Subjek penelitian ini berjumlah 10 orang anak kelas B di Taman Kanak-kanak Zulhijjah Medan. Sesuai dengan tuntunan penelitian tindakan kelas, maka diterapkan metode penelitian berparadigma ganda yaitu metode kuantitatif dan kualitatif. Data kuantitatif dianalisis dengan menggunakan uji-t,

\footnotetext{
*Corresponding Armanila, Email: armanila@gmail.com
} 
sampel berpasangan (t-paired samples) untuk mengetahui peningkatan kecerdasan interpersonal dan intrapersonal sebelum dan sesudah dilakukan tindakan, serta melihat perbedaan pada tiap-tiap siklus, sedangkan data kualitatif dianalisis berdasarkan hasilobservasi yang telah dilakukan. Hasil penelitian menunjukkan, bahwa adanya perbedaan yang signifikan dalam peningkatan kecerdasan interpersonal dan intrapersonal melalui pembelajaran tematik, pada assesmen awal dan assesmen akhir, setelah dilakukan penghitungan dengan menggunakan uji-t, maka hasilnya adalah sebagai berikut: 1) t-hitung kecerdasan interpersonal= $-19,844$ lebih kecil dari nilai ttabel= 2,262, 2) t-hitung kecerdasan intrapersonal=-18,253 lebih kecil dari nilai t-tabel= 2,262 dengan demikian dapat dikatakan bahwa terdapat peningkatan antara assemen awal dan assesmen akhir pada tingkat kepercayaan 95\% terhadap kecerdasan interpersonal dan intrapersonal. Hal ini juga terlihat pada pra tindakan dengan nilai ratarata kecerdasan interpersonal sebesar $40,62 \%$ lalu pada siklus I meningkat menjadi $64,79 \%$, dan diakhir siklus II telah mencapai $82,70 \%$ demikian juga pada kecerdasan intrapersonal yaitu memiliki nilai rata-rata pada pra tindakan sebesar 43,95\% lalu pada siklus I meningkat menjadi 63,75\% dan diakhir siklus II telah mencapai 80,41\%. Dari temuan penelitian ini dapat disimpulkan bahwa, untuk meningkatkan kecerdasan interpersonal dan intrapersonal anak usia dini (5-6 tahun) perlu memperhatikan pembelajaran tematik yang digunakan.

Kata kunci: kecerdasan interpersonal, kecerdasan intrapersonal, pembelajaran tematik.

\section{A. PENDAhULUAN}

Anak usia dini ialah anak yang baru dilahirkan sampai dengan usia 6 tahun. Usia dini merupakan usia yang sangat fundamental dalam menentukan pembentukan karakter dan kepribadian seorang anak. Usia dini merupakan usia dimana seorang anak akan mengalami pertumbuhan dan perkembangan yang sangat pesat. Oleh karena itu, usia dini disebut sebagai usia emas (golden age). Dimana makanan bergizi yang seimbang dan stimulasi yang intensif sangat dibutuhkan anak untuk pertumbuhan dan perkembangan selanjutnya.

Adapun upaya yang telah dilakukan pemerintah untuk mengoptimalkan seluruh potensi yang terdapat pada anak usia dini ialah melalui jalur pendidikan anak usia dini (PAUD). Sebagaimana yang terdapat pada UU No. 20 Tahun 2003 Pasal 1 ayat 14 yang berbunyi bahwa pendidikan anak usia dini adalah suatu upaya pembinaan yang ditujukan kepada anak sejak lahir sampai dengan usia enam tahun yang dilakukan melalui pemberian rangsangan pendidikan untuk membantu pertumbuhan dan perkembangan jasmani dan rohani agar anak memiliki kesiapan dalam memasuki pendidikan lebih lanjut. Peranan para pemegang kebijakan pendidikan sangat penting untuk menciptakan lingkungan yang dapat merangsang seluruh potensi anak agar dapat berkembang dengan optimal. Pendidikan anak usia 4-6 tahun, merupakan masa peka bagi anak yaitu anak mulai sensitif menerima 


\section{Armanila}

berbagai upaya perkembangan seluruh potensinya. Masa peka ialah masa terjadinya pematangan fungsi-fungsi fisik dan psikis yang siap merespons stimulasi yang diberikan oleh lingkungan. Masa ini merupakan masa untuk meletakkan dasar pertama dalam mengembangkan kemampuan fisik, kognitif, bahasa, akhlakul karimah, dan pendidikan agamanya. Peningkatan mutu pendidikan merupakan prioritas utama dalam penyelenggaraan pendidikan nasional. Berbagai upaya telah dilakukan untuk meningatkan mutu pendidikan melalui penyelenggaraan pendidikan yang ada bisa menghasilkan sumber daya manusia yang berkualitas. Sumber daya manusia dikatakan berkualitas bilamana mereka mampu mengembangkan kecerdasan interpersonal dan kecerdasan intrapersonal.

Gardner (dalam Amstrong, 1994) mengemukakan bahwa kecerdasan interpersonal ialah kemampuan mempersepsi dan membedakan suasana hati, maksud, motivasi serta perasaan orang lain serta kemampuan memberikan respons secara tepat terhadap suasana hati, temperamen, motivasi serta keinginan orang lain. Adapun Contoh anak usia 5-6 tahun yang memiliki kecerdasan ini capaian perkembangannya telah mampu menunjukkan sikap bergantian ketika bermain, berangkat ke sekolah tanpa diantar oleh orang tua/pengasuh, merapikan alat bermain dan memainkan mainan sesuai dengan fungsinya, tertib dan dapat menunggu giliran dalam segala kegiatan, memahami akibat jika melakukan pelanggaran dan berani bertanggungjawab, dapat menjadi memimpin kelompok bermain (antara 4-8 orang), serta terampil memecahkan masalah sederhana. Sedangkan kecerdasan intrapersonal menurut Gardner (dalam Amstrong, 1994) ialah kemampuan memahami diri sendiri dan bertindak berdasarkan pemahaman tersebut. Adapun Contoh anak usia 5-6 tahun yang memiliki kecerdasan ini capaian perkembangannya telah mampu menunjukkan sikap berbagi mainan dan mengajak teman bermain, senang merenung atau berpikir ketika sendirian, sering mengungkapkan cita-citanya kepada orang lain, berani tampil di depan kelas, dan menunjukkan hasil karyanya, selalu aktif dalam bermain, mampu menetapkan target bermain, misalnya menyusun balok dalam waktu 10 menit, selalu bersemangat ketika bermain, sering menyendiri, berkhayal dan berpikir, sering menunjukkan mainan kebanggaannya kepada orang lain, dan diam ketika marah.

Sedangkan kecerdasan interpersonal dan intrapersonal yang dikembangkan sejak usia dini sangat penting untuk pengembangan kecerdasan anak secara optimal. Hal senada juga diungkapkan oleh Gardner (dalam Megawangi, 2005) bahwa 


\section{Armanila}

kecerdasan adalah kemampuan untuk menyelesaikan berbagai masalah dalam kehidupan dan dapat menghasilkan barang atau jasa yang berguna dalam berbagai aspek kehidupan. Oleh karena itu, guru dan khususnya orang tua harus dapat mendeteksi kecerdasan ini. Hal ini dapat dilihat pada awal anak mulai berkomunikasi secara verbal. Tinggi rendahnya kadar kecerdasan ini tergantung pada stimulasi yang diberikan oleh orang tua dan guru di sekolah.

Dengan demikian, pengembangan kecerdasan interpersonal dan intrapersonal sejak usia dini bermanfaat untuk dapat menyelesaikan berbagai masalah dalam kehidupan dan dapat menghasilkan barang atau jasa yang berguna dalam berbagai aspek kehidupan. Jadi, apabila kecerdasan ini tidak dikembangkan pada saat usia dini maka akan timbul berbagai masalah dalam kehidupannya kelak. Seperti Fenomena yang terjadi pada bangsa Indonesia saat ini adalah telah rapuhnya rasa solidaritas sosial antar sesama, saling curiga, tidak saling menghargai, mementingkan kepentingan individu di atas kepentingan orang banyak. Terjadi tauran antar suku, ras dan agama. Tauran antar pelajar, antar kelompok masyarakat, dan sebagainya. Lebih ironis lagi adalah moral dan nilai-nilai agama tidak dijadikan pedoman dalam kehidupan sehari-hari.

Hal di atas, diperkuat dengan hasil penelitian yang dilakukan oleh Masganti (2009) dengan judul optimalisasi kompetensi moral anak usia dini, dimana dari hasil penelitiannya disimpulkan bahwa pembelajaran terpadu/tematik berbasis moral dapat mengoptimalkan kompetensi moral anak usia dini. yaitu ketika sebelum dilakukannya intervensi tindakan kompetensi moral anak dalam kategori cukup namun setelah dilakukannya intervensi tindakan maka kompetensi moral anak dalam kategori baik. Dengan demikian, disimpulkan bahwa pembelajaran tematik dapat meningkatkan kecerdasan interpersonal dan intrapersonal anak usia dini pada Taman Kanak-kanak.

Guru anak usia dini dituntut untuk dapat memahami dan melaksanakan dengan baik pembelajaran tematik, dengan kegiatan pembelajaran yang terintegrasi antara aspek pengembangan dengan menggunakan tema yang subur, dan lebih menekankan pada keterlibatan siswa secara aktif dalam proses pembelajaran, Hal senada juga diungkapkan oleh Seefeldt dan Barbour (1994) bahwa tema adalah pokok pikiran atau gagasan pokok yang menjadi pokok pembicara. Dengan penerapan pembelajaran tematik tersebut siswa dapat memperolah pengalaman langsung dan terlatih untuk menemukan sendiri berbagai pengetahuan yang dipelajarinya. Sebab 


\section{Armanila}

melalui pengalaman langsung siswa akan dapat memahami konsep-konsep yang mereka pelajari dan menghubungkannya dengan konsep lain yang telah dipahaminya.

Di Taman Kanak-kanak Zulhijjah dimana penelitian ini dilakukan, setelah peneliti amati belum sepenuhnya mengembangkan kecerdasan interpersonal dan intrapersonal secara terprogram dalam pembelajaran. Oleh karena itu peneliti tertarik dan merasa perlu untuk melakukan penelitian dalam mengoptimalkan kecerdasan interpersonal dan intrapersonal anak usia 5-6 tahun. Selain itu, dalam pelaksanaan pembelajaran tematik yang diterapkan masih terkotak-kotak yaitu belum tertuang ke dalam satuan mingguan (RKM) dan satuan kegiatan harian (RKH) dan begitu juga dalam pelaksanaannya masih dalam bentuk yang sangat sederhana serta belum menggambarkan kemampuan anak secara holistik.

Adapun prosedur pembelajaran tematik di Taman kanak-kanak (TK) yang dikemukakan oleh Rohde (1991) yaitu: 1) Menentukan tema. 2) Mengembangkan tema menjadi sub tema yang lebih spesifik untuk dijadikan topik dalam pembelajaran. 3) Mendesain rencana pembelajaran sesuai dengan tema. 4) Merancang rencana kegiatan mingguan. 5) Memperhatikan manajemen kelas. 6) Menyediakan media pembelajaran. 7) Menciptakan suasana tematik. 8) Melaksanakan pembelajaran di luar perencanaan artinya memanfaatkan kejadian spontan diluar perencanaan untuk menambah pemahaman anak karena dari konsep itu mereka akan berekplorasi. 9) Melaksanakan penilaian terhadap pemahaman dan minat anak melalui observasi. 10) Melakukan evalusi pembelajaran. 11) Menentukan perluasan tema bila minat anak-anak mengenai tema tersebut besar. Beranjak dari kondisi belum terstimulasi kecerdasan interpersonal dan intrapersonal anak, peneliti merasa perlu untuk meneliti apakah ada perbaikan terhadap pembelajaran tematik untuk meningkatkan kecerdasan interpersonal dan intrapersonal anak, dengan demikian, judul yang diteliti yaitu:"Upaya Meningkatkan Kecerdasan Interpersonal dan Intrapersonal Melalui Pembelajaran Tematik Di Taman Kanak-kanak (5-6 Tahun) Zulhijjah Medan."

\section{B. METODOLOGI PENELITIAN}

Penelitian ini menggunakan metode penelitian tindakan kelas (classroom action research). Artinya penelitian yang bersifat reflektif dengan melakukan tindakantindakan tertentu, agar dapat memperbaiki dan atau meningkatkan praktek-praktek 
pembelajaran di kelas secara profesional. Dalam penelitian ini, yang diperbaiki adalah sistem pembelajaran untuk meningkatkan kecerdasan interpersonal dan intrapersonal melalui pembelajaran tematik. Di Taman Kanak-kanak Zulhijjah Medan.

Penelitian ini dilaksanakan dengan menggunakan model Kemmis dan Taggart (1999). Adapun prosedur pelaksanaan penelitian ini melalui empat tahap yaitu 1) perencanaan (planning), 2) tindakan (acting), 3) observasi (observation), dan 4) refleksi (reflection). Tahapan ini terus berulang sampai suatu permasalahan dianggap teratasi untuk kemudian diikuti oleh kemunculan permasalahan lain yang juga harus diperlukan serupa. Keempat fase kegiatan dari suatu siklus penelitian tindakan digambarkan dengan sebuah spiral, sebagaimana yang terlihat pada gambar. 1 :

\section{Gambar. 1}

\section{Desain Penelitian Intervensi Tindakan}

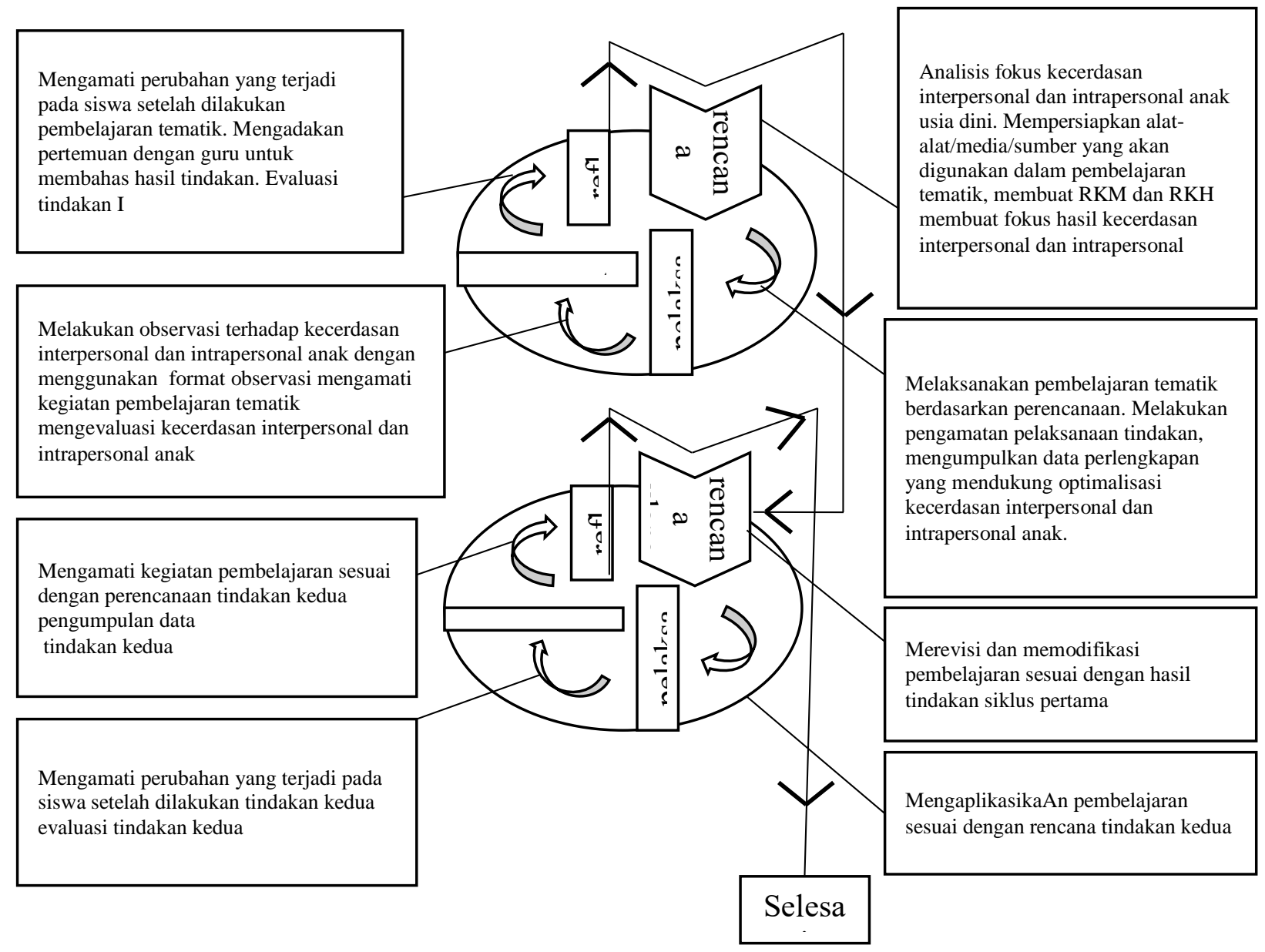

\section{HASIL DAN PEMBAHASAN}

\section{Analisis Data Kualitatif}

Analisis data kualitatif menggunakan Spradley (1980). Hasil analisis data kualitatif panelitian ini dapat dilihat sebagai berikut: 
Hasil Analisis Domain Kecerdasan Interpersonal dan Intrapersonal Melalui Pembelajaran Tematik Pada Kelompok B Taman Kanak-Kanak Zulhijjah Medan (Siklus I dan Siklus II)

\begin{tabular}{|c|c|}
\hline Siklus I & Siklus II \\
\hline $\mathrm{X}$ adalah termasuk $\mathrm{Y}$ & $\mathrm{X}$ adalah termasuk $\mathrm{Y}$ \\
\hline $\begin{array}{l}\text { Menyebutkan pengertian perilaku- } \\
\text { perilaku kecerdasan interpersonal dan } \\
\text { intrapersonal adalah termasuk } \\
\text { mengoptimalkan kecerdasan } \\
\text { interpersonal dan intrapersonal anak } \\
\text { melalui pembelajaran tematik }\end{array}$ & $\begin{array}{l}\text { Menyebutkan beberapa pengertian } \\
\text { perilaku-perilaku kecerdasan } \\
\text { interpersonal dan intrapersonal adalah } \\
\text { termasuk mengoptimalkan kecerdasan } \\
\text { interpersonal dan intrapersonal anak } \\
\text { melalui pembelajaran tematik }\end{array}$ \\
\hline $\begin{array}{l}\text { Menyebutkan alasan melakukan } \\
\text { perilaku kecerdasan interpersonal dan } \\
\text { intrapersonal adalah termasuk } \\
\text { mengoptimalkan kecerdasan } \\
\text { interpersonal dan intrapersonal anak } \\
\text { melalui pemeblajaran tematik }\end{array}$ & $\begin{array}{l}\text { Menyebutkan alasan melakukan } \\
\text { perilaku kecerdasan interpersonal dan } \\
\text { intrapersonal adalah termasuk } \\
\text { mengoptimalkan kecerdasan } \\
\text { interpersonal dan intrapersonal anak } \\
\text { melalui pemeblajaran tematik }\end{array}$ \\
\hline $\begin{array}{l}\text { Menyebutkan berabgai cara melakukan } \\
\text { tindakan keceradsan interpersonal dan } \\
\text { intrapersonal adalah termasuk } \\
\text { mengoptimalkan kecerdasan } \\
\text { interpersonal dan intrapersonal anak } \\
\text { melalui pembelajaran tematik }\end{array}$ & $\begin{array}{l}\text { Menyebutkan berabgai cara } \\
\text { melakukan tindakan keceradsan } \\
\text { interpersonal dan intrapersonal adalah } \\
\text { termasuk mengoptimalkan kecerdasan } \\
\text { interpersonal dan intrapersonal anak } \\
\text { melalui pemeblajaran tematik }\end{array}$ \\
\hline Siklus I & Siklus II \\
\hline$X$ adalah termasuk $Y$ & $\mathrm{X}$ adalah termasuk $\mathrm{Y}$ \\
\hline $\begin{array}{l}\text { Menceritakan pengalaman anak } \\
\text { melakukan kecerdasan interpersonal } \\
\text { dan intrapersonal dengan kalimat yang } \\
\text { sederhana adalah termasuk } \\
\text { mengoptimalkan kecerdasan } \\
\text { interpersonal dan intrapersonal anak } \\
\text { melalui pembelajaran tematik }\end{array}$ & $\begin{array}{l}\text { Menceritakan pengalaman anak } \\
\text { melakukan kecerdasan interpersonal } \\
\text { dan intrapersonal dengan kalimat } \\
\text { yang sederhana adalah termasuk } \\
\text { mengoptimalkan kecerdasan } \\
\text { interpersonal dan intrapersonal anak } \\
\text { melalui pembelajaran tematik }\end{array}$ \\
\hline $\begin{array}{l}\text { Memilih gambar yang disukai anak yang } \\
\text { berkaitan dengan kecerdasan } \\
\text { interpersonal dan intrapersonal dan } \\
\text { tidak kecerdasan interpersonal dan } \\
\text { intrapersonal adalah termasuk } \\
\text { mengoptimalkan kecerdasan } \\
\text { interpersonal dan intrapersonal anak } \\
\text { melalui pembelajaran tematik }\end{array}$ & $\begin{array}{l}\text { Memilih gambar yang disukai anak } \\
\text { yang berkaitan dengan kecerdasan } \\
\text { interpersonal dan intrapersonal dan } \\
\text { tidak kecerdasan interpersonal dan } \\
\text { intrapersonal adalah termasuk } \\
\text { mengoptimalkan kecerdasan } \\
\text { interpersonal dan intrapersonal anak } \\
\text { melalui pembelajaran tematik }\end{array}$ \\
\hline $\begin{array}{l}\text { Menyatakan perasaan senang ketika } \\
\text { melakukan perilaku yang berkaitan dan } \\
\text { tidak berkaitan dengan kecerdasan } \\
\text { interpersonal dan intrapersonal adalah } \\
\text { termasuk mengoptimalkan kecerdasan }\end{array}$ & $\begin{array}{l}\text { Menyatakan perasaan senang ketika } \\
\text { melakukan perilaku yang berkaitan } \\
\text { dan tidak berkaitan dengan } \\
\text { kecerdasan interpersonal dan } \\
\text { intrapersonal adalah termasuk } \\
\text { mengoptimalkan kecerdasan }\end{array}$ \\
\hline
\end{tabular}




\begin{tabular}{|c|c|}
\hline $\begin{array}{l}\text { interpersonal dan intrapersonal anak } \\
\text { melalui pembelajaran tematik }\end{array}$ & $\begin{array}{l}\text { interpersonal dan intrapersonal anak } \\
\text { melalui pembelajaran tematik }\end{array}$ \\
\hline $\begin{array}{l}\text { Mengingatkan anak agar dapat } \\
\text { mengantri, menjadi pemimpin, tertib, } \\
\text { bertanggungjawab, mengelola emosi, } \\
\text { percayadiri, memiliki motivasi serta } \\
\text { dapat menetapkan target bermain } \\
\text { adalah termasuk mengoptimalkan } \\
\text { kecerdasan interpersonal dan } \\
\text { intrapersonal anak melalui } \\
\text { pembelajaran tematik }\end{array}$ & $\begin{array}{l}\text { Mengingatkan anak agar dapat } \\
\text { mengantri, menjadi pemimpin, tertib, } \\
\text { bertanggungjawab, mengelola emosi, } \\
\text { percayadiri, memiliki motivasi serta } \\
\text { dapat menetapkan target bermain } \\
\text { adalah termasuk mengoptimalkan } \\
\text { kecerdasan interpersonal dan } \\
\text { intrapersonal anak melalui } \\
\text { pembelajaran tematik }\end{array}$ \\
\hline Siklus I & \\
\hline $\mathrm{X}$ adalah terma & $\mathrm{X}$ adalah $\mathrm{t}$ \\
\hline $\begin{array}{l}\text { Mengingatkan anak untuk } \\
\text { mendengarkan dan memperhatikan } \\
\text { orang lain ketika berbicara adalah } \\
\text { termasuk mengoptimalkan kecerdasan } \\
\text { interpersonal dan intrapersonal anak } \\
\text { melalui pembelajaran tematik }\end{array}$ & $\begin{array}{l}\text { Menunjukkan contoh } \\
\text { tertib dalam belajar ac } \\
\text { mengoptimalkan kece } \\
\text { interpersonal dan intr } \\
\text { melalui pembelajaran }\end{array}$ \\
\hline $\begin{array}{l}\text { Memuji anak yang te } \\
\text { tindakan kecerdasan } \\
\text { intrapersonal adalah } \\
\text { mengoptimalkan kec } \\
\text { interpersonal dan int } \\
\text { melalui pembelajaral }\end{array}$ & $\begin{array}{l}\text { tindakan kecerdasan int } \\
\text { intrapersonal adalah ter } \\
\text { mengoptimalkan kecerc } \\
\text { interpersonal dan intra } \\
\text { melalui pembelajaran te }\end{array}$ \\
\hline Siklus I & \\
\hline$X$ ad: & \\
\hline $\begin{array}{l}\text { Pengembangan dan pembiasaan } \\
\text { kecerdasan interpersonal dan } \\
\text { intrapersonal dilakukan ketika anak } \\
\text { melakukan tindakan yang tidak sesuai } \\
\text { dengan kecerdasan interpersonal dan } \\
\text { intrapersonal adalah termasuk } \\
\text { mengoptimalkan kecerdasan } \\
\text { interpersonal dan intrapersonal anak } \\
\text { melalui pembelajaran tematik }\end{array}$ & $\begin{array}{l}\text { Pengembangan dan pembiasaan } \\
\text { kecerdasan interpersonal dan } \\
\text { intrapersonal hanya dilakukan ketika } \\
\text { anak melakukan tindakan yang tidak } \\
\text { sesuai dengan kecerdasan } \\
\text { interpersonal dan intrapersonal } \\
\text { adalah termasuk mengoptimalkan } \\
\text { kecerdasan interpersonal dan } \\
\text { intrapersonal anak melalui } \\
\text { pembelajaran tematik }\end{array}$ \\
\hline $\begin{array}{l}\text { Kurangnya media film dan media } \\
\text { gambar yang digunakan untuk } \\
\text { mengoptimalkan kecerdasan } \\
\text { interpersonal dan intrapersonal anak } \\
\text { adalah alasan untuk menggunakan - }\end{array}$ & $\begin{array}{l}\text { Belum tercapainya target penelitian } \\
\text { tindakan pada dimensi tindakan } \\
\text { kecerdasan interpersonal dan } \\
\text { intrapersonal adalah alasan untuk } \\
\text { menggunakan media audio visual - }\end{array}$ \\
\hline & \\
\hline $\mathrm{X}$ adalah alasa & $\mathrm{X}$ adalah ala \\
\hline $\begin{array}{l}\text { media audio yaitu bentuk film dan media } \\
\text { gambar sebagai media dalam } \\
\text { mengoptimalkan kecerdasan } \\
\text { interpersonal dan intrapersonal anak } \\
\text { melalui pembelajaran tematik. }\end{array}$ & $\begin{array}{l}\text { berupa film dan media gambar sebagai } \\
\text { contoh bagi anak dan latihan dalam } \\
\text { melakukan tindakan kecerdasan } \\
\text { interpersonal dan intrapersonal dalam } \\
\text { pembelajaran tematik }\end{array}$ \\
\hline
\end{tabular}




\begin{tabular}{|c|c|}
\hline $\begin{array}{l}\text { Masih belum terbiasa anak melakukan } \\
\text { tindakan kecerdasan interpersonal dan } \\
\text { intrapersonal adalah alasan untuk selalu } \\
\text { memberikan nasehat kepada anak untuk } \\
\text { melakukan tindakan-tindakan } \\
\text { kecerdasan interpersonal dan } \\
\text { intrapersonal }\end{array}$ & $\begin{array}{l}\text { Masih belum terbiasa anak melakukan } \\
\text { tindakan kecerdasan interpersonal dan } \\
\text { intrapersonal adalah alasan untuk } \\
\text { selalu memberikan nasehat dan latihan } \\
\text { kepada anak untuk melakukan } \\
\text { tindakan-tindakan kecerdasan } \\
\text { interpersonal dan intrapersonal }\end{array}$ \\
\hline $\begin{array}{l}\text { Anak mampu menyebutkan dan } \\
\text { menjelaskan pengertian tindakan- } \\
\text { tindakan tentang kecerdasan } \\
\text { interpersonal dan intrapersonal, alasan- } \\
\text { alasan melakukan tindakan-tindakan } \\
\text { kecerdasan interpersonal dan } \\
\text { intrapersonal, cara-cara melakukan } \\
\text { tindakan kecerdasan interpersonal dan } \\
\text { intrapersonal adalah hasil optimalisasi } \\
\text { kecerdasan interpersonal dan } \\
\text { intrapersonal anak melalui } \\
\text { pembelajaran tematik }\end{array}$ & $\begin{array}{l}\text { Anak mampu menyebutkan dan } \\
\text { menjelaskan pengertian tindakan- } \\
\text { tindakan tentang kecerdasan } \\
\text { interpersonal dan intrapersonal, } \\
\text { alasan-alasan melakukan tindakan- } \\
\text { tindakan kecerdasan interpersonal } \\
\text { dan intrapersonal, cara-cara } \\
\text { melakukan tindakan kecerdasan } \\
\text { interpersonal dan intrapersonal } \\
\text { adalah hasil optimalisasi kecerdasan } \\
\text { interpersonal dan intrapersonal anak } \\
\text { melalui pembelajaran tematik }\end{array}$ \\
\hline $\begin{array}{l}\text { h gambar tentang } \\
\text { ang sesuai dan tidak } \\
\text { lasan interpersonal } \\
\text { alah hasil } \\
\text { san interpersonal } \\
\text { ak melalui } \\
\text { k }\end{array}$ & $\begin{array}{l}\text { Anak mampu memilih gambar tentang } \\
\text { tindakan-tindakan yang sesuai dan } \\
\text { tidak sesuai dengan kecerdasan } \\
\text { interpersonal dan intrapersonal } \\
\text { adalah hasil optimalisasi kecerdasan } \\
\text { interpersonal dan intrapersonal anak } \\
\text { melalui pembelajaran tematik }\end{array}$ \\
\hline & \\
\hline $\mathrm{X}$ adalah alas & elakukan Y \\
\hline $\begin{array}{l}\text { Anak mampu menunjukkan perilaku } \\
\text { mengantri dalam bermain ayunan, } \\
\text { mengantri bermain perosotan dan } \\
\text { mengantri bermain enjotan, menjadi } \\
\text { pemimpin dalam kelompok bermain, } \\
\text { mengarahkan temannya dalam } \\
\text { kelompok bermain, dapat menjadi } \\
\text { pemimpin sampai akhir bermain, } \\
\text { merapikan alat bermain ke tempatnya } \\
\text { kembali, merapikan alat bermain dengan } \\
\text { hati-hati, memainkan alat permainan } \\
\text { sesuai dengan fungsinya, datang tepat } \\
\text { waktu ke sekolah, membersihkan } \\
\text { tempat makan setelah selesai makan, } \\
\text { membuang sampah pada tempatnya, } \\
\text { tidak menjerit ketika temannya } \\
\text { mengambil mainannya, tidak berbicara } \\
\text { kasar ketika temannya mengambil } \\
\text { mainannya, tidak menangis ketika } \\
\text { temannya mengambil mainannya, tampil }\end{array}$ & $\begin{array}{l}\text { Anak mampu menunjukkan perilaku } \\
\text { mengantri dalam bermain ayunan, } \\
\text { mengantri bermain perosotan dan } \\
\text { mengantri bermain enjotan, menjadi } \\
\text { pemimpin dalam kelompok bermain, } \\
\text { mengarahkan temannya dalam } \\
\text { kelompok bermain, dapat menjadi } \\
\text { pemimpin sampai akhir bermain, } \\
\text { merapikan alat bermain ke tempatnya } \\
\text { kembali, merapikan alat bermain } \\
\text { dengan hati-hati, memainkan alat } \\
\text { permainan sesuai dengan fungsinya, } \\
\text { datang tepat waktu ke sekolah, } \\
\text { membersihkan tempat makan setelah } \\
\text { selesai makan, membuang sampah } \\
\text { pada tempatnya, tidak menjerit ketika } \\
\text { temannya mengambil mainannya, } \\
\text { tidak berbicara kasar ketika temannya } \\
\text { mengambil mainannya, tidak } \\
\text { menangis ketika temannya mengambil } \\
\text { mainannya, tampil membaca doa } \\
\text { sendirian, berani tampil di depan }\end{array}$ \\
\hline
\end{tabular}




\begin{tabular}{|c|c|}
\hline $\begin{array}{l}\text { karyanya, aktif dalam kegiatan bermain, } \\
\text { mengajak temannya bermain, } \\
\text { mengambil peran dalam kegaitan } \\
\text { bermain, menyusun balok dalam tempo } \\
10 \text { menit, anak dapat menyusun pazel } \\
\text { dalam tempo 20- }\end{array}$ & $\begin{array}{l}\text { kelas, tampil menunjukkan hasil } \\
\text { karyanya, aktif dalam kegiatan } \\
\text { bermain, mengajak temannya bermain, } \\
\text { mengambil peran dalam kegaitan } \\
\text { bermain, menyusun balok dalam } \\
\text { tempo } 10 \text { menit, anak dapat menyusun } \\
\text { pazel- }\end{array}$ \\
\hline Siklus I & Siklus II \\
\hline $\mathrm{X}$ adalah alasan melakukan $\mathrm{Y}$ & $\mathrm{X}$ adalah alasan melakukan $\mathrm{Y}$ \\
\hline $\begin{array}{l}\text { menit, anak dapat menyusun bongkar } \\
\text { pasang dalam tempo } 10 \text { menit adalah } \\
\text { hasil optimalisasi kecerdasan } \\
\text { interpersonal dan intrapersonal anak } \\
\text { melalui pembelajaran tematik. }\end{array}$ & $\begin{array}{l}\text { dalam tempo } 20 \text { menit, anak dapat } \\
\text { menyusun bongkar pasang dalam } \\
\text { tempo } 10 \text { menit adalah hasil } \\
\text { optimalisasi kecerdasan interpersonal } \\
\text { dan intrapersonal anak melalui } \\
\text { pembelajaran tematik. }\end{array}$ \\
\hline $\begin{array}{l}\text { Guru menunjukkan } \mathrm{f} \\
\text { memperhatikan film } \\
\text { mengoptimalkan kec } \\
\text { interpersonal dan in } \\
\text { melalui pembelajara }\end{array}$ & $\begin{array}{l}\text { Guru menunjukkan film dan anak } \\
\text { memperhatikan film tersebut secara } \\
\text { perkelompok adalah untuk } \\
\text { mengoptimalkan kecerdasan } \\
\text { interpersonal dan intrapersonal anak } \\
\text { melalui pembelajaran tematik }\end{array}$ \\
\hline $\begin{array}{l}\text { Guru menunjul } \\
\text { memperhatika } \\
\text { untuk mengopt } \\
\text { interpersonal d } \\
\text { melalui pembe }\end{array}$ & $\begin{array}{l}\text { ambar dan anak } \\
\text { bar adalah untuk } \\
\text { erdasan } \\
\text { trapersonal anak } \\
\text { n tematik }\end{array}$ \\
\hline $\begin{array}{l}\text { Guru bercerita dan bertanya tentang } \\
\text { kecerdasan interpersonal dan } \\
\text { intrapersonal anak dalam gambar adalah } \\
\text { cara untuk mengoptimalkan kecerdasan } \\
\text { interpersonal dan intrapersonal anak } \\
\text { melalui pembelajaran tematik }\end{array}$ & $\begin{array}{l}\text { ak menjawab } \\
\text { terpersonal dan } \\
\text { lam gambar } \\
\text { ngoptimalkan } \\
\text { onal dan } \\
\text { elalui } \\
\end{array}$ \\
\hline $\begin{array}{l}\text { Melakukan tanya jawab tentang } \\
\text { pengetahuan kecerdasan interpersonal } \\
\text { dan intrapersonal dan perasaan } \\
\text { kecerdasan interpersonal dan- }\end{array}$ & $\begin{array}{l}\text { Melakukan tanyajawab tentang } \\
\text { pengetahuan kecerdasan } \\
\text { interpersonal dan intrapersonal dan } \\
\text { perasaan kecerdasan interpersonal } \\
\text { dan- }\end{array}$ \\
\hline Sik & Siklus II \\
\hline $\mathrm{X}$ adalah alasa & $\mathrm{X}$ adalah alasan melakukan $\mathrm{Y}$ \\
\hline $\begin{array}{l}\text { intrapersonal adalah cara untuk } \\
\text { mengoptimalkan kecerdasan } \\
\text { interpersonal dan intrapersonal anak } \\
\text { melalui pembelajaran tematik }\end{array}$ & $\begin{array}{l}\text { intrapersonal adalah cara untuk } \\
\text { mengoptimalkan kecerdasan } \\
\text { interpersonal dan intrapersonal anak } \\
\text { melalui pembelajaran tematik }\end{array}$ \\
\hline $\begin{array}{l}\text { Melatih anak dengan cara membiasakan } \\
\text { anak untuk melakukan tindakan- } \\
\text { tindakan kecerdasan interpersonal dan } \\
\text { intrapersonal adalah cara untuk } \\
\text { mengoptimalkan kecerdasan }\end{array}$ & $\begin{array}{l}\text { Menunjukkan contoh tokoh yang } \\
\text { melakukan perilaku-perilaku yang } \\
\text { berkaitan dengan kecerdasan } \\
\text { interpersonal dan intrapersonal melalu } \\
\text { gambar adalah cara untuk } \\
\text { mengoptimalkan kecerdasan } \\
\end{array}$ \\
\hline
\end{tabular}




\begin{tabular}{|l|l|}
\hline $\begin{array}{l}\text { interpersonal dan intrapersonal anak } \\
\text { melalui pembelajaran tematik }\end{array}$ & $\begin{array}{l}\text { interpersonal dan intrapersonal anak } \\
\text { melalui pembelajaran tematik }\end{array}$ \\
\hline Memberikan penguatan dengan cara & Memberikan penguatan dengan cara \\
memuji langsung ketika anak melakukan & memuji langsung ketika anak \\
perilaku yang berkaitan dengan & melakukan perilaku yang berkaitan \\
kecerdasan interpersonal dan & dengan kecerdasan interpersonal dan \\
intrapersonal adalah cara untuk & intrapersonal adalah cara untuk \\
mengoptimalkan kecerdasan & mengoptimalkan kecerdasan \\
interpersonal dan intrapersonal anak & interpersonal dan intrapersonal anak \\
melalui pembelajaran tematik & melalui pembelajaran tematik \\
\hline
\end{tabular}

\section{b) Analisis Taksonomi}

Hasil analisis taksonomi dari pengamatan terfokus pada siklus pertama dan siklus dua dapat dilihat pada gambar-gambar berikut ini:

\section{Tabel 2.}

Analisis Taksonomi Materi Meningkatkan Kecerdasan Interpersonal dan Intrapersonal Anak Usia Dini melalui Pembelajaran Tematik Siklus I

\begin{tabular}{|l|l|l|}
\hline \multicolumn{3}{|c|}{ Kegiatan yang Dilakukan untuk Meningkatkan } \\
\hline \multicolumn{1}{|c|}{ Pengetahuan } & \multicolumn{1}{|c|}{ Perasaan } & Tindakan \\
\hline 1) $\begin{array}{l}\text { Anak menonton dan } \\
\text { memperhatikan film }\end{array}$ & $\begin{array}{c}\text { 1) Anak mengungkapkan } \\
\text { perasaannya ketika }\end{array}$ & 1) Konsisten \\
mengingatkan anak \\
yang berkaitan dengan & melakukan tindakan & untuk mengantri \\
kecerdasan & perilaku yang berkaitan & 2) Konsisten \\
interpersonal dan & dengan kecerdasan & mengingatkan anak \\
intrapersonal & interpersonal dan & untuk memimpin \\
Anak melihat dan & intrapersonal & 3) Konsisten \\
memperhatikan gambar & 2) Anak menyatakan rasa & mengingatkan anak \\
yang berkaitan dengan & senang ketika ia dapat & untuk tertib \\
kecerdasan & melakukan tindakan & 4) Konsisten \\
interpersonal dan & perilaku yang berkaitan & mengingatkan anak \\
intrapersonal & dengan kecerdasan & untuk \\
Anak menjawab & interpersonal dan & bertanggungjawab \\
pertanyaan yang & intrapersonal & 5) Konsisten \\
berkaitan dengan & & mengingatkan anak \\
pengertian tindakan & & untuk mengelola \\
perilaku dari & & emosinya \\
kecerdasan & & 6) Konsisten \\
interpersonal dan & & mengingatkan anak \\
intrapersonal, alasan & & untuk memiliki \\
melakukannya, dan & & motivasi \\
melakukannya sendiri. & & 7) Konsisten \\
Anak memilih gambar & & mengingatkan anak \\
yang benar berkaitan & & untuk percaya diri \\
dengan tindakan & & 8) Konsisten \\
perilaku dari & mengingatkan anak \\
kecerdasan & & \\
\hline
\end{tabular}




\begin{tabular}{|l|l|l|}
\hline $\begin{array}{l}\text { interpersonal dan } \\
\text { intrapersonal }\end{array}$ & $\begin{array}{l}\text { untuk menetapkan } \\
\text { target bermain }\end{array}$ \\
\hline
\end{tabular}

Tabel 3.

Analisis Taksonomi Materi meningkatkan Kecerdasan Interpersonal dan Intrapersonal Anak Usia Dini Melalui Pembelajaran Tematik Siklus II

\begin{tabular}{|c|c|c|}
\hline \multicolumn{3}{|c|}{$\begin{array}{l}\text { Kegiatan yang Dilakukan untuk Meningkatkankan } \\
\text { Kecerdasan Interpersonal dan Intrapersonal Anak }\end{array}$} \\
\hline Pengetahuan & Perasaan & Tindakan \\
\hline $\begin{array}{l}\text { 1) Menonton dan } \\
\text { memperhatikan film } \\
\text { yang berkaitan dengan } \\
\text { kecerdasan } \\
\text { interpersonal dan } \\
\text { intrapersonal } \\
\text { 5) Melihat dan } \\
\text { memperhatikan gambar } \\
\text { yang berkaitan dengan } \\
\text { kecerdasan } \\
\text { interpersonal dan } \\
\text { intrapersonal } \\
\text { Menjawab pertanyaan } \\
\text { yang berkaitan dengan } \\
\text { pengertian tindakan } \\
\text { perilaku dari } \\
\text { kecerdasan } \\
\text { interpersonal dan } \\
\text { intrapersonal, alasan } \\
\text { melakukannya, dan } \\
\text { melakukannya sendiri. } \\
\text { Memilih gambar yang } \\
\text { benar berkaitan dengan } \\
\text { tindakan perilaku dari } \\
\text { kecerdasan } \\
\text { interpersonal dan } \\
\text { intrapersonal }\end{array}$ & $\begin{array}{l}\text { 1) Mengungkapkan } \\
\text { perasaan anak-anak } \\
\text { ketika melakukan } \\
\text { perilaku tindakan } \\
\text { yang berkaitan } \\
\text { dengan kecerdasan } \\
\text { interpersonal dan } \\
\text { intrapersonal } \\
\text { 3) Menyatakan rasa } \\
\text { kesedihannya ketika } \\
\text { ia tidak dapat } \\
\text { melakukan perilaku } \\
\text { tindakan yang } \\
\text { berkaitan dengan } \\
\text { kecerdasan } \\
\text { interpersonal dan } \\
\text { intrapersonal }\end{array}$ & $\begin{array}{l}\text { 1) Mengajak anak untuk } \\
\text { mengantri dalam segala } \\
\text { kegiatan } \\
\text { 2) Memberi kesempatan } \\
\text { pada anak untuk } \\
\text { menjadi memimpin } \\
\text { 3) Mengajak anak untuk } \\
\text { bersikap tertib dalam } \\
\text { bermain dengan } \\
\text { menggunakan alat } \\
\text { bermain } \\
\text { 4) Memberi kesempatan } \\
\text { kepada anak untuk } \\
\text { bertanggungjawab } \\
\text { 5) Memberi kesempatan } \\
\text { mengingatkan anak } \\
\text { untuk mengelola } \\
\text { emosinya } \\
\text { 6) Memeri kesempatan } \\
\text { mengingatkan anak } \\
\text { untuk memiliki } \\
\text { motivasi } \\
\text { 7) Memberi kesempatan } \\
\text { kepada anak untuk } \\
\text { percaya diri } \\
\text { 9) Memberikan } \\
\text { kesempatan kepada } \\
\text { anak untuk } \\
\text { menetapkan target } \\
\text { bermain }\end{array}$ \\
\hline
\end{tabular}

Tabel 4.

Analisis Taksonomi Media Meningkatkan Kecerdasan Interpersonal dan Intrapersonal Anak Usia Dini Melalui Pembelajaran Tematik Siklus II

Media yang Digunakan untuk Meningkatkan Kecerdasan Interpersonal dan Intrapersonal Anak

\begin{tabular}{|l|l} 
Media Audio Visual (Film) & Media Audio Visual (Film)
\end{tabular} 
1) Film anak yang bergantian bermain perosotan, enjotan dan ayunan dalam mengoptimalkan perilaku mengantri pada kecerdasan interpersonal

2) Film anak yang menjadi pemimpin kelompok bermain dan mengarahkan temannya dalam bermain guna mengoptimalkan sikap kepemimpinan pada kecerdasan interpersonal

3) Film anak yang bermain kreta api, pesawat terbang, masak-masakan dan boneka serta merapikan kembali mainannya setelah selesai bermain dalam mengoptimalkan perilaku tertib pada kecerdasan interpersonal

4) Film anak yang bertanggungjawab terhadap kebersihan dan tepat waktu masuk kelas dalam mengoptimalkan perilaku mengantri pada kecerdasan interpersonal

5) Film anak yang mematuhi peraturan sekolah dalam mengoptimalkan emosi anak pada kecerdasan intrapersonal

6) Film anak yang tentang sikap percaya diri dalam mengoptimalkan perilaku percaya diri anak pada kecerdasan intrapersonal

7) Film anak yang tentang bermain biola kaki dan basket di halaman sekolah dalam mengoptimalkan emosi anak pada kecerdasan intrapersonal

8) Film anak yang menyusun pazel dan balok dalam waktu yang telah ditentukan dalam mengoptimalkan tindakan mennetukan target main anak pada kecerdasan intrapersonal
1) Gambar anak yang mengantri dan tidak mengantri dalam bermain perosotan, enjotan, ayunan dalam mengoptimalkan perilaku mengantri pada kecerdasan interpersonal

2) Gambar anak yang menjadi pemimpin dalam kegiatan bermain dan dapat mengarahkan temannya dalam mengoptimalkan sikap kepemimpinan pada kecerdasan interpersonal

3) Gambar anak yang sedang bermain mobil-mobilan, masakmasakan, dan balok serta gambar anak yang merapikan alat bermainnya kembali dalam mengoptimalkan perilaku tertib pada kecerdasan interpersonal

4) Gambar anak yang membersihkan tempat makan, membuang sampah ke tong sampah, dan gambar anak yang datang tepat waktu ke sekolah dalam bermain perosotan, enjotan, ayunan dalam mengoptimalkan perilaku mengantri pada kecerdasan interpersonal

5) Gambar anak yang berbicara sopan ketika temannya mengambil mainannya dan gambar anak yang bermain secara damai dengan temannya dalam mengoptimalkan emosi anak pada kecerdasan intrapersonal

6) Gambar anak yang tampil ke depan kelas, tampil membaca doa sendirian, dan tampil menunjukkan hasil karyanya dalam mengoptimalkan perilaku percaya diri anak pada kecerdasan intrapersonal

7) Gambar anak yang aktif bermain, ikut bermain bersama teman dan mengikut sertakan temannya dalam bermain dalam mengoptimalkan motivasi anak pada kecerdasan intrapersonal 
8) Gambar anak yang menyusun pazel, bongkar pasang dan balok dalam mengoptimalkan perilaku menetapkan target bermain anak pada kecerdasan intrapersonal

\section{Analisis Kuantitatif}

Untuk mengoptimalkan kecerdasan interpersonal dan intrapersonal anak Taman Kanak-kanak kelompok B. Sebelum melakukan penelitian, peneliti bersama guru berdiskusi tentang cara menggunakan model pembelajaran tematik yang akan digunakan di Taman Kanak-kanak Zulhijjah Medan. Pelaksanaan tindakan ini dilakukan selama 2 minggu, namun sebelum melaksanakan perlakuan, terlebih dahulu peneliti melakukan assesmen awal pada Taman Kanak-kanak Zulhijjah kelompok B yang akan menjadi subjek dalam penelitian. Berikut ini data hasil perhitungan assesmen awal, dapat dilihat pada tabel. 7 berikut:

Tabel. 5

Nilai Kecerdasan Interpersonal Anak Kelompok B Taman Kanak-kanak Zulhijjah Medan (Assesmen Awal)

\begin{tabular}{|c|c|c|}
\hline No subjek & $\begin{array}{c}\text { Nilai kecerdasan } \\
\text { Interpersonal }\end{array}$ & Jumlah \\
\hline 1 & 26 & 26 \\
\hline 2 & 18 & 18 \\
\hline 3 & 26 & 26 \\
\hline 4 & 24 & 24 \\
\hline 5 & 15 & 15 \\
\hline 6 & 20 & 20 \\
\hline 7 & 18 & 18 \\
\hline 8 & 18 & 18 \\
\hline 9 & 17 & 17 \\
\hline 10 & 13 & 13 \\
\hline Rerata & 19,5 & 19,5 \\
\hline Median & 17 & 17 \\
\hline Nilai Tertinggi & 26 & 26 \\
\hline Nilai Terendah & 13 & 13 \\
\hline Modus & 18 & 18 \\
\hline Standar Deviasi & 2,67 & 2,67 \\
\hline Mean & 19,5 & 19,5 \\
\hline
\end{tabular}

Berdasarkan hasil assesment awal kecerdasan interpersonal anak Taman Kanak-kanak Zulhijjah median sebesar 17, mode 18, dan standar deviasi sebesar 2,67, berdasarkan perhitungan data kecerdasan interpersonal pada tabel di atas, bahwa 
assesmen awal kecerdasan interpersonal anak Taman Kanak-kanak Zulhijjah berada pada kategori BB (belum berkembang)

Namun jika dilihat dari hasil tiap dimensi maka hasil tes tersebut dapat dilihat pada gambar. 2 berikut:

Gambar. 2

\section{Skor Kecerdasan Interpersonal Anak Assesmen Awal}

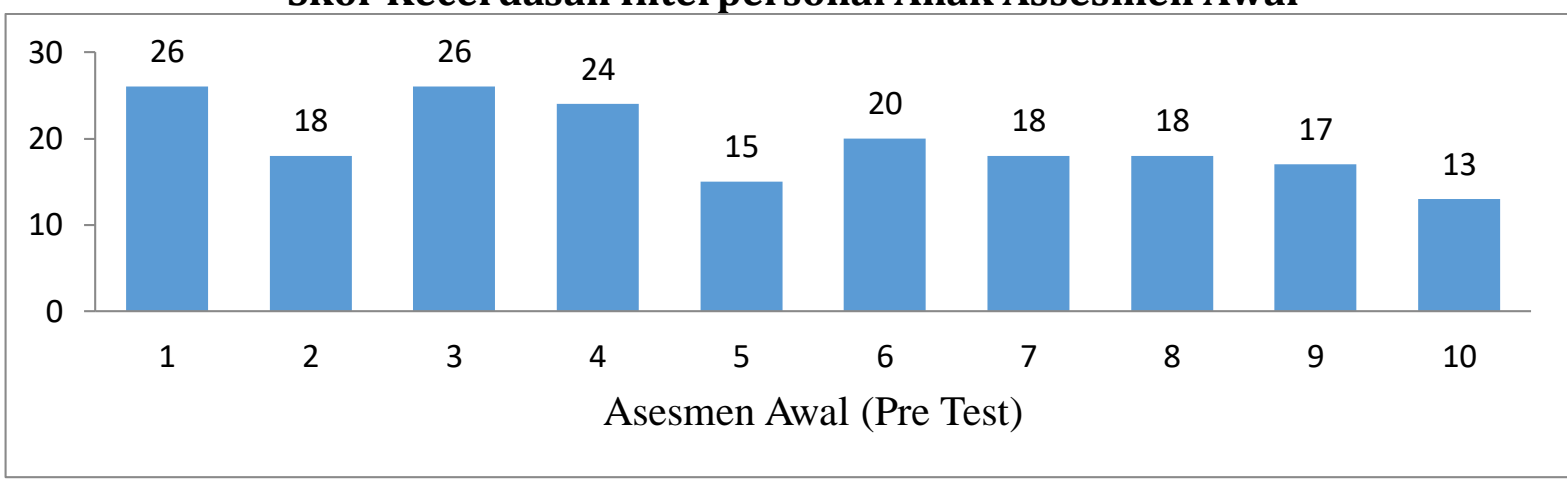

Berdasarkan data di atas, menunjukkan bahwa kecerdasan interpersonal anak Taman Kanak-kanak TK B Zulhijjah masih perlu ditingkatkan. Sesuai dengan tujuan penelitian untuk mengoptimalkan kecerdasan interpersonal anak akan dilakukan dalam bentuk pelaksanaan pembelajaran tematik.

Proses pembelajaran dilakukan selama dalam waktu dua minggu, setelah itu peneliti melakukan tes akhir pada anak TK B Zulhijjah yang sebelumnya telah mendapatkan perlakuan. Hasil tes akhir dapat dilihat pada tabel. 8 berikut:

Tabel. 6

Nilai Kecerdasan Interpersonal Anak Kelompok B Taman Kanak-kanak Zulhijjah Medan (Assesmen Akhir)

\begin{tabular}{|c|c|c|}
\hline No subjek & $\begin{array}{c}\text { Nilai kecerdasan } \\
\text { Interpersonal }\end{array}$ & Jumlah \\
\hline 1 & 45 & 45 \\
\hline 2 & 44 & 44 \\
\hline 3 & 45 & 45 \\
\hline 4 & 44 & 44 \\
\hline 5 & 36 & 36 \\
\hline 6 & 40 & 40 \\
\hline 7 & 31 & 31 \\
\hline 9 & 39 & 39 \\
\hline 10 & 37 & 37 \\
\hline Rerata & 32 & 32 \\
\hline Median & 39,3 & 39,3 \\
\hline Nilai Tertinggi & 36 & 36 \\
\hline Nilai Terendah & 45 & 45 \\
\hline Modus & 31 & 31 \\
\hline Standar Deviasi & 44 dan 45 & 44,5 \\
\hline Mean & 4,63 & 4,63 \\
\hline Range & 39,3 & 39,3 \\
\hline
\end{tabular}


Berdasarkan hasil perhitungan statistik bahwa kecerdasan interpersonal anak TK B Zulhijjah adalah sebagai berikut; nilai rata-rata 39,3, median 36, mode 44 dan 45, standar deviasi 4,63. Dengan melihat hasil yang diperoleh menunjukkan bahwa kecerdasan anak TK B Zulhijjah berada pada kategori BSH (berkembang sesuai harapan).

Di bawah ini hasil kecerdasan interpersonal anak sebelum dan sesudah perlakuan dapat dilihatpada gambar. 3 berikut:

Gambar. 6

Peningkatan Kecerdasan Interpersonal Anak Assesmen Awal dan Assesmen Akhir

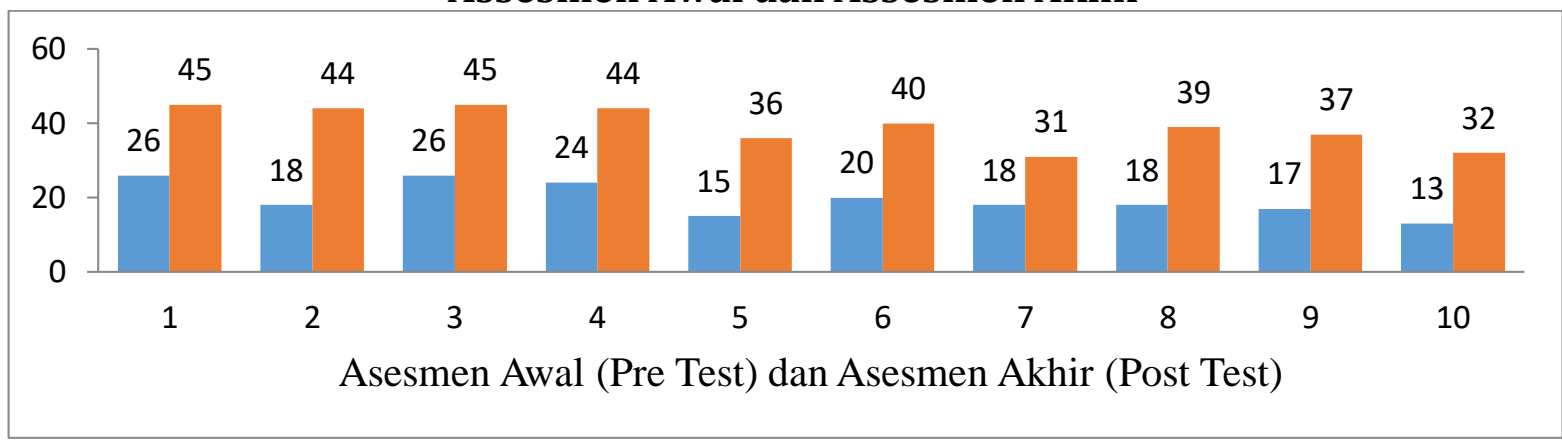

Berdasarkan analisis data asessmen awal dan akhir pada kecerdasan interpersonal bahwa pada tiap siklus menggunakan uji t sampel berpasangan $(t$ paired sampel). Dengan menggunakan SPSS persi 17.0, maka hasil perhitungan uji t dari assesmen bahwa kecerdasan interpersonal anak usia dini sebelum dan sesudah dilakukan tindakan melalui pembelajaran tematik diperoleh $t_{\text {hitung }}=\quad-19,844$.

Tabel. 7

Nilai Kecerdasan Intrapersonal Anak Kelompok B Taman Kanak-kanak Zulhijjah Medan (Assesmen Awal)

\begin{tabular}{|c|c|c|}
\hline No subjek & $\begin{array}{c}\text { Nilai kecerdasan } \\
\text { Interpersonal }\end{array}$ & Jumlah \\
\hline 1 & 25 & 25 \\
\hline 2 & 25 & 25 \\
\hline 3 & 19 & 19 \\
\hline 5 & 25 & 25 \\
\hline 6 & 15 & 15 \\
\hline 7 & 24 & 24 \\
\hline 8 & 15 & 15 \\
\hline 9 & 24 & 24 \\
\hline 10 & 24 & 24 \\
\hline Rerata & 15 & 15 \\
\hline Median & 21,1 & 21,1 \\
\hline Nilai Tertinggi & 25 & 25 \\
\hline Nilai Terendah & 25 & 25 \\
\hline Modus & 15 & 15 \\
\hline Standar Deviasi & 15,24 dan 25 & 21,3 \\
\hline Mean & 2,7 & 2,7 \\
\hline Range & 21,1 & 21,1 \\
\hline
\end{tabular}


Berdasarkan hasil assesment awal keceradsan intrapersonal anak Taman Kanak-kanak Zulhijjah sebesar median 25, mode 15, 24 dan 25, dan standar deviasi sebesar 2,7, berdasarkan perhitungan data kecerdasan intrapersonal pada tabel dia atas, bahwa assesmen awal kecerdasan intrapersonal anak Taman Kanak-kanak Zulhijjah berada pada kategori BB (belum berkembang)

Namun jika dilihat dari hasil tiap dimensi maka hasil tes tersebut dapat dilihat pada gambar. 7 berikut ini:

Gambar. 7

Skor Kecerdasan Intrapersonal Anak Assesmen Awal

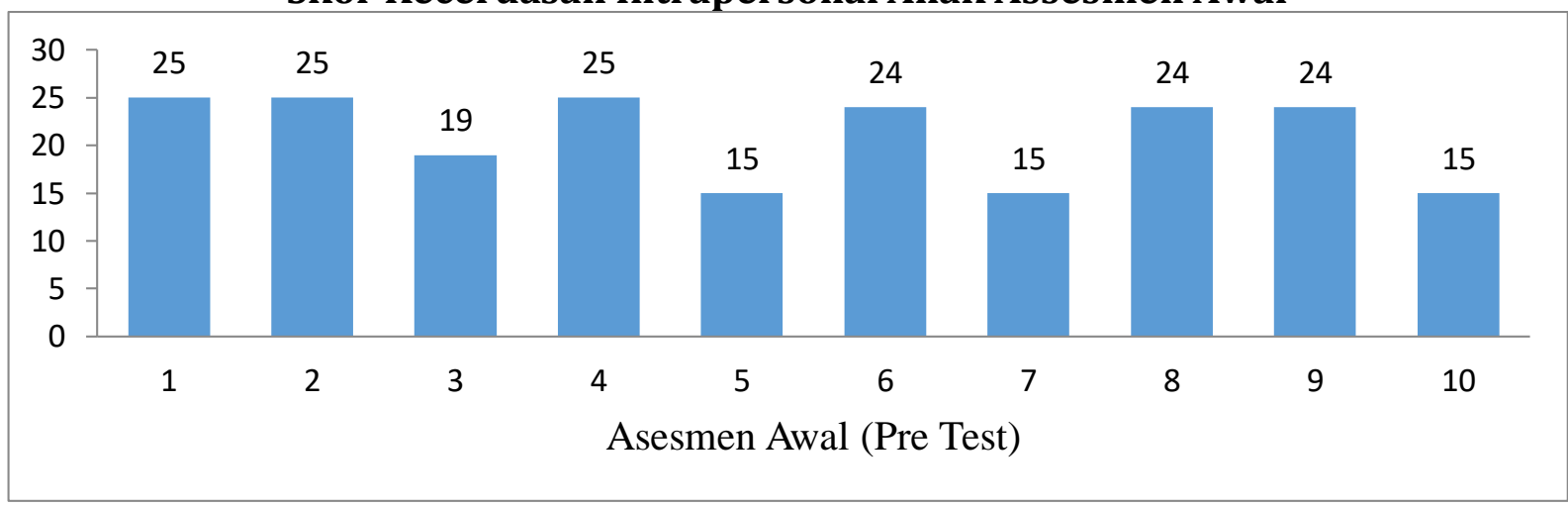

Berdasarkan data di atas, menunjukkan bahwa kecerdasan intrapersonal anak Taman Kanak-kanak TK B Zulhijjah masih perlu ditingkatkan. Sesuai dengan tujuan penelitian untuk mengoptimalkan kecerdasan intrapersonal anak akan dilakukan dalam bentuk melakukan pelaksanaan pembelajaran tematik.

Proses pembelajaran dilakukan selama dalam waktu dua minggu, setelah itu peneliti melakukan tes akhir pada anak TK B Zulhijjah yang sebelumnya telah mendapatkan perlakuan. Hasil tes akhir dapat dilihat pada tabel. 9. berikut ini:

Tabel. 10

Nilai Kecerdasan Intrapersonal Anak Kelompok B Taman Kanak-kanak Zulhijjah Medan (Assesmen Akhir)

\begin{tabular}{|c|c|c|}
\hline No subjek & $\begin{array}{c}\text { Nilai kecerdasan } \\
\text { Interpersonal }\end{array}$ & Jumlah \\
\hline 1 & 45 & 45 \\
\hline 2 & 43 & 43 \\
\hline 3 & 42 & 42 \\
\hline 4 & 44 & 44 \\
\hline 5 & 32 & 32 \\
\hline 6 & 39 & 39 \\
\hline 7 & 32 & 32 \\
\hline 8 & 37 & 37 \\
\hline
\end{tabular}




\begin{tabular}{|l|c|c|}
\hline \multicolumn{1}{|c|}{9} & 39 & 39 \\
\hline \multicolumn{1}{|c|}{10} & 30 & 30 \\
\hline Rerata & 38,3 & \\
\hline Median & 39 & \\
\hline Nilai Tertinggi & 45 & \\
\hline Nilai Terendah & 30 & \\
\hline Modus & 32 dan 39 & \\
\hline Standar Deviasi & 4,98 & \\
\hline Mean & 38,3 & \\
\hline
\end{tabular}

Berdasarkan hasil perhitungan statistik bahwa kecerdasan intrapersonal anak TK B Zulhijjah adalah sebagai berikut; nilai rata-rata 38,3, median 39, mode 32 dan 39 standar deviasi 4,98. Dengan melihat hasil yang diperoleh menunjukkan bahwa kecerdasan anak TK B Zulhijjah berada pada kategori BSH (berkembang sesuai harapan).

Di bawah ini hasil kecerdasan intrapersonal anak sebelum dan sesudah perlakuan dapat dilihat pada gambar. 8 berikut:

Gambar. 5

Peningkatan Kecerdasan Intrapersonal Anak Assesmen Awal dan Assesmen Akhir

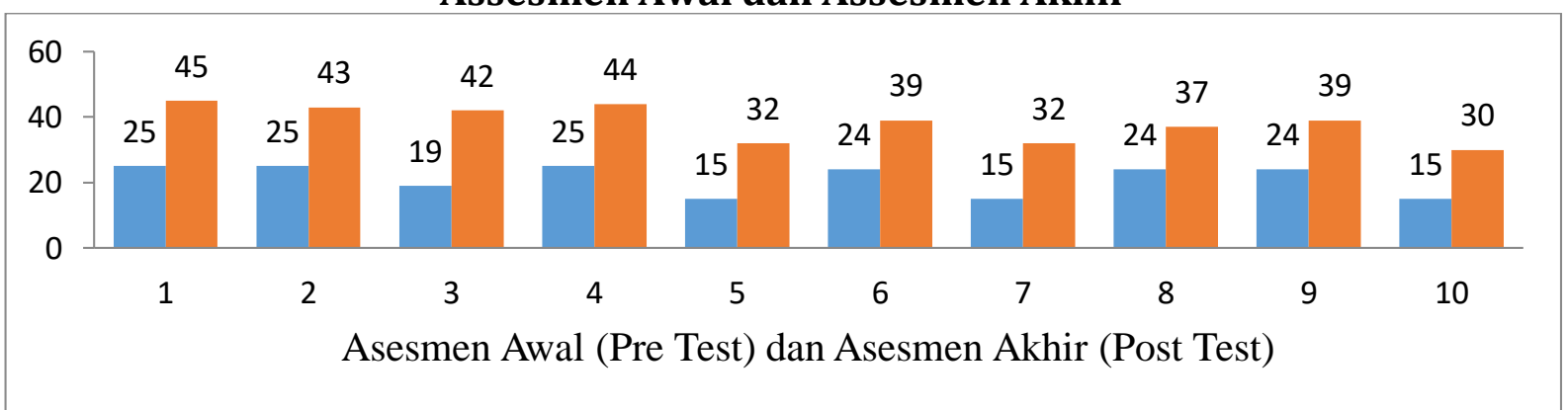

Berdasarkan analisis data asessmen awal dan akhir pada kecerdasan intrapersonal bahwa pada tiap siklus menggunakan uji t sampel berpasangan $(t$ paired sampel). Dengan menggunakan SPSS persi 17.0, maka hasil perhitungan uji t dari assesmen bahwa kecerdasan intrapersonal anak usia dini sebelum dan sesudah dilakukan tindakan melalui pembelajaran tematik diperoleh $t_{\text {hitung }}=\quad-18,253$.

\section{Pengujian Hipotesis Penelitian Tindakan}

Berdasarkan hasil pengujian hipotesis dalam pelaksanaan tindakan maka:"pembelajaran tematik dapat meningkatkan kecerdasan interpersonal dan intrapersonal anak Taman Kanak-kanak kelompok B". berdasarkan ketentuan di bawah ini:

a) Ho di tolak jika $t$ hitung $>t$ tabel 
b) Ho di terima jika $t_{\text {hitung }}<t_{\text {tabel }}$

Berdasarkan perhitungan assesmen kecerdasan interpersonal anak usia dini sebelum dan sesudah melakukan tindakan pembelajaran tematik dengan menggunakan uji t sampel berpasangan diperoleh $t$ hitung $=-19,844$. Sedangkan nilai $t$ tabel 0,05 Hasil perhitungan tersebut menunjukkan Ho ditolak, dengan demikian terdapat perbedaan yang signifikan pada rata-rata kecerdasan interpersonal anak usia dini sebelum dan sesudah perlakuan. Hal ini menunjukkan bahwa pembelajaran tematik dapat meningkatkan kecerdasan interpersonal anak usia dini.

Demikian juga pada perhitungan assesmen kecerdasan intrapersonal anak usia dini sebelum dan sesudah melakukan tindakan pembelajaran tematik dengan menggunakan uji t sampel berpasangan diperoleh $t$ hitung $=-18,253$. Sedangkan nilai $t$ tabel 0,05 Hasil perhitungan tersebut menunjukkan Ho ditolak, dengan demikian terdapat perbedaan yang signifikan pada rata-rata kecerdasan interpersonal anak usia dini sebelum dan sesudah perlakuan. Hal ini menunjukkan bahwa pembelajaran tematik dapat meningkatkan kecerdasan intrapersonal anak usia dini.

\section{SIMPULAN}

Berdasarkan proses dan hasil dari pelaksanaan penelitian tindakan kelas dan didukung hasil uji efektifitas temuan penelitian, secara umum dapat simpulkan sebagai berikut:"Pembelajaran tematik dapat meningkatkan kecerdasan interpersonal dan intrapersonal anak usia dini"di Taman Kanak-kanak Zulhijjah Medan. Secara khusus, hasil penelitian ini dapat menjawab pertanyaan penelitian yang diajukan, yakni sebagai berikut: 1) Kecerdasan interpersonal anak meningkat, setelah dilaksanakannya pembelajaran tematik. Dengan kegiatan yang mencakup pengembangan kecerdasan interpersonal anak, media film, media gambar dan lembar kerja anak, serta metode pembelajaran dengan mengamati gambar dan kerja kelompok, tanya jawab, penugasan dan bimbingan, nasehat, penguatan serta praktek langsung dapat mengembangkan kecerdasan interpersonal anak, pada pra tindakan nilai rata-rata kecerdasan interpersonal anak 40,62\% lalu pada siklus I meningkat menjadi 64,79\% dan di akhir siklus II telah mencapai 82,70\% yaitu berkembang sesuai harapan. Kemudian peningkatan ini juga dapat dilihat pada hasil assesmen awal dan akhir yaitu memiliki $\mathrm{t}$ hitung $=-19,844$ lebih kecil dari $\mathrm{t}$ tabel $=2,262$. Selanjutnya sebagai dampak dari pembelajaran, anak dapat menampilkan dalam kegiatan sehari-hari di sekolah: anak mengetahui bagaimana caranya menunggu giliran ketika bermain, tertib menggunakan alat bermain, bertanggungjawab dan 


\section{Armanila}

mampu memimpin kelompok bermain. 2) Kecerdasan intrapersonal anak meningkat, setelah dilaksanakannya pembelajaran tematik. Dengan kegiatan yang mencakup pengembangan kecerdasan intrapersonal anak, media film, media gambar dan lembar kerja anak, serta metode pembelajaran dengan mengamati gambar dan kerja kelompok, tanya jawab, penugasan dan bimbingan, nasehat, penguatan serta praktek langsung dapat mengembangkan kecerdasan interpersonal anak, pada pra tindakan nilai rata-rata kecerdasan interpersonal anak 43,95\% lalu pada siklus I meningkat menjadi 63,75\% dan di akhir siklus II telah mencapai 80,41\%\% yaitu berkembang sesuai harapan. Kemudian peningkatan ini juga dapat dilihat pada hasil assesmen awal dan akhir yaitu memiliki $\mathrm{t}$ hitung $=-18,253$ lebih kecil dari $\mathrm{t}$ tabel $=2,262$. Selanjutnya sebagai dampak dari pembelajaran, anak dapat menampilkan dalam kegiatan sehari-hari di sekolah: mengendalikan emosinya, percaya diri, memiliki motivasi, dan menetapkan target dalam bermain.

Berdasarkan proses dan hasil dari pelaksanaan penelitian tindakan kelas dan didukung hasil uji efektifitas temuan penelitian, secara umum dapat simpulkan sebagai berikut:"Pembelajaran tematik dapat meningkatkan kecerdasan interpersonal dan intrapersonal anak usia dini"di Taman Kanak-kanak Zulhijjah Medan. Secara khusus, hasil penelitian ini dapat menjawab pertanyaan penelitian yang diajukan, yakni sebagai berikut: 1) Kecerdasan interpersonal anak meningkat, setelah dilaksanakannya pembelajaran tematik. Dengan kegiatan yang mencakup pengembangan kecerdasan interpersonal anak, media film, media gambar dan lembar kerja anak, serta metode pembelajaran dengan mengamati gambar dan kerja kelompok, tanya jawab, penugasan dan bimbingan, nasehat, penguatan serta praktek langsung dapat mengembangkan kecerdasan interpersonal anak, pada pra tindakan nilai rata-rata kecerdasan interpersonal anak 40,62\% lalu pada siklus I meningkat menjadi $64,79 \%$ dan di akhir siklus II telah mencapai $82,70 \%$ yaitu berkembang sesuai harapan. Kemudian peningkatan ini juga dapat dilihat pada hasil assesmen awal dan akhir yaitu memiliki $\mathrm{t}$ hitung $=-19,844$ lebih kecil dari $\mathrm{t}$ tabel $=2,262$. Selanjutnya sebagai dampak dari pembelajaran, anak dapat menampilkan dalam kegiatan sehari-hari di sekolah: anak mengetahui bagaimana caranya menunggu giliran ketika bermain, tertib menggunakan alat bermain, bertanggungjawab dan mampu memimpin kelompok bermain. 2) Kecerdasan intrapersonal anak meningkat, setelah dilaksanakannya pembelajaran tematik. Dengan kegiatan yang mencakup pengembangan kecerdasan intrapersonal anak, media film, media gambar dan 
Armanila

lembar kerja anak, serta metode pembelajaran dengan mengamati gambar dan kerja kelompok, tanya jawab, penugasan dan bimbingan, nasehat, penguatan serta praktek langsung dapat mengembangkan kecerdasan interpersonal anak, pada pra tindakan nilai rata-rata kecerdasan interpersonal anak 43,95\% lalu pada siklus I meningkat menjadi $63,75 \%$ dan di akhir siklus II telah mencapai $80,41 \% \%$ yaitu berkembang sesuai harapan. Kemudian peningkatan ini juga dapat dilihat pada hasil assesmen awal dan akhir yaitu memiliki $\mathrm{t}$ hitung $=-18,253$ lebih kecil dari $\mathrm{t}$ tabel $=2,262$. Selanjutnya sebagai dampak dari pembelajaran, anak dapat menampilkan dalam kegiatan sehari-hari di sekolah: mengendalikan emosinya, percaya diri, memiliki motivasi, dan menetapkan target dalam bermain.

\section{DAFTAR PUSTAKA}

Amstrong,T, 1994, Multiple Intellegences in the Classroom, Virginia: Association for supervision and Curriculum Development. Kaifa. ,2002, Multiple Intellegences in the Classroom, Terjemahan Yudhi Murtanto, Jakarta:

Asrori, M. 2003, Perkembangan Peserta Didik, Malang: Wineka Media.

Borg R and E.M Gall, 1997, Educational Research: An Introduction:Fifth Edition, New York: Longmon.

Bronson, Martha B., 1999, The Right Stuff: Selecting Play Materials to Support Development, Washington D.C.: National Association for the Education of young Children.

Collin, G dan Dixon, 1991, Integrated learning: Planned Curriculum Unit, Iinois: IRI/Skylight Puplishing, Inc.

Dahlan, 1990, Model-model Mengajar (Beberapa Alternatif Interaksi Belajar Mengajar), Bandung: CV. Diponogoro.

Fakhruddin, Umar, A, 2010, Sukses menjadi Guru TK-PAUD. Jogjakarta: Bening. Fogarty, R.1991, How To Integrate The Curricula, Palatitine: IRI/Skylight Training and Puplishing, Inc.

Gardner, H. 2003, Kecerdasan Majemuk (Multiple Intelligences) Teori Dan Praktek, Alih Bahasa Alexsander Sindoro, Interaksara.

— 2013, Multiple Intellegence Memaksimalkan Potensi dan Kecerdasan Individu dari Masa Kanak-kanak Hingga Dewasa, Terjemahan Yelvi Andri Zaimur, Jakarta: Daras Book. 1999, Intellegence Reframed, New York: Basic Books. 
Armanila

Jamaris, M, 2010, Orientasi Baru dalam Psikologi Pendidikan, Jakarta: Yayasan Penamas Murni.

,2008, Pembelajaran Tematik”, Makalah tidak diterbitkan disampaikan pada seminar nasional dan workshop "Pembelajaran Tematik", Medan: Universitas Negeri Medan, 25 Agustus 2008.

Isaac, S. 1980, Handbook In Research And Education, San Diego: Science ITB.

Khadijah, 2012, Konsep Dasar Pendidikan Anak Usia Dini, Bandung: Citapustaka Media Perintis.

, 2011, Kemandirian Anak Usia Dini Melalui Pembelejaran tematik: Penelitian Tindakan pada TK di Kota Medan, Disertasi tidak diterbitkan Jakarta: UNJ.

Kemmis, S dan Mc Taggart, R, 1999, The Action Research Planner, Victoria, Deakin University.

Mariyana, R, 2005, Strategi Pengelolaan Lingkungan Belajar di Taman Kanak-kanan, Jakarta: Departemen Pendidikan Nasional.

Maryam, 2010, Penggunaan Bermain Peran (Pasar-pasaran) dalam Meningkatkan Kecerdasan Interpersonal Anak. Skripsi. Tidak Diterbitkan, UMS.

Masganti, S, 2009, Optimalisasi Kompetensi Moral Anak Usia Dini, Disertasi tidak diterbitkan Jakarta: UNJ.

Megawangi, R dkk, 2005, Pendidikan Holistik, Jakarta: Indonesia Heritage Foundation.

Musfiroh, T, 2008, Pengembangan Kecerdasan Jamak, Jakarta: Universitas Terbuka.

— 2008, Cerdas Melalui Bermain Cara Mengasah Multiple Intellegences pada Anak Sejak Usia Dini, Jakarta: PT. Grasindo.

Mangoenprasodjo, A, S, dan Hidayati, , N.S, 2005, Anak Masa Depan dengan Multiple Intelegensi, Yogyakarta: Pradipta Puplishing, 2005.

Niff, Mc. J. 1992, Action Research:Prinsiple and Practice, London.

Romiszowski, A.J. 1981, Designing Intructional, New York: Kogen Page.

Rohde, B, dkk, 1991, Teaching Young Children Using Themes, America: Good Year Books.

Setyono, 10.2008, Pengaruh Kecerdasan Intrapersonal dan Media Pembelajaran Terhadap PrestasBelajar".http://setyono.blogspot.com/2008/11/pengaruh-kecerdasan-intrapersonaldan.html.

Seefeldt, C and Barbour, N, 1994, Early Childhood Education, New York:Merril Puplishing Company.

Spencer dan Kass, 1970, Perspektivesin Child Psychology, New York: MC Graw Hill Book Company. 
Armanila

Safaria, T. (2005) Interpersonal Intelligence: Metode Pengembangan Kecerdasan Interpersonal Anak. Yogyakarta: Amara Books.

Santrock, JW, 2007, Psikologi Pendidikan, Terjemahan Tri Wibowo, Jakarta: Kencana Prenada Media Group.

Santoso, S. 2002, Pendidikan Anak Usia Dini, Jakarta: Citra Pendidikan.

Spradley, James, P. 1980, The Ethnographic Interview, New York: Holt, Rinehart and Winston.

Suharsimi, A, 2000, Manajemen Penelitian, Jakarta: PT. Rineka Cipta.

Suyadi. 2010, Psikologi Belajar PAUD, Yogyakarta : Pustaka Insan Madani

Soetjiningsih, Tumbuh kembang anak, Jakarta: EGC.1995

Suyanto, S, Dasar-dasar Pendidikan Anak Usia Dini, Yogyakarta: Hikayat Puplishing, 2005.

Undang-Undang Republik Indonesia No.20 tahun 2003 Tentang Sistem Pendidikan Nasional, Jakarta: Eka Jaya, 2003. 